LSP International Journal, Vol. 8, Issue 1, 2021, 81-94

(C) Universiti Teknologi Malaysia

E-ISSN 2601-002X

DOI: https://doi.org/10.11113/lspi.v8.17233

\title{
Patterns of Teacher Trainee Grammar Talk in Second Language Classrooms
}

\author{
Tina Abdullah*, Fauziah Ismail, Zubaidah Awang \& Azian Abd. Aziz@Ahmad \\ Language Academy, Faculty of Social Sciences and Humanities \\ Universiti Teknologi Malaysia \\ 81310 UTM Johor Bahru, Johor Malaysia
}

Submitted: 12/8/2019. Revised edition: 24/6/2021 Accepted: 25/06/2021. Published online: 28/6/2021

\begin{abstract}
Literature in Language Teacher Education (LTE) has highlighted that teaching of grammar should be included as a foundational framework for all language teaching. This indicates that teacher trainees need to be trained with a firm foundation for grammar teaching in language classrooms. Thus, an investigation on how teacher trainees taught grammar and the pattern of their grammar instruction can provide insights to teacher trainees and teacher educators on grammar teaching methodology practised in language classrooms. By understanding how teacher trainees present grammar in their classrooms and what patterns emerged from their grammar instruction can lead to ongoing process of searching for better grammar teaching in language classrooms. This article shares the findings on an investigation conducted on how and what was practised by teacher trainees in their grammar instruction. Two prevalent patterns were discovered. Transmission technique which is teacher fronted and interaction technique which is teacher-student-teacher fronted were commonly practised by the trainees. However, the teacher-fronted technique dominates the interaction technique. This signals that teacher educators need to promote more interactive techniques in the LTE programme so that trainees are trained to teach grammar by utilising more interactive techniques such as questioning (to use more convergent and divergent questions instead of literal questions) and giving corrective feedback (to elicit and recast instead of repeating) which promote two-way grammar teaching.
\end{abstract}

Keywords: LTE, grammar, instruction, teacher trainee

\section{INTRODUCTION}

There has been an increasing level of attention on grammar education in Language Teacher Education (LTE) (Navaz and Khaathoon, 2020). Teacher educators raise issues on what grammar to teach; how grammar can be taught; why grammar needs to be taught in a particular manner; and what options in grammar teaching teacher trainees should consider during their grammar instruction. These issues signal that the teaching of grammar is a complex matter and more insights are needed to understand teachers' grammar teaching practices.

Language researchers (Borg, 1999; Ellis, 1998, 2002; Burgess and Etherington, 2002; Azar, 2007; Schurz and Coumel, 2020) argue that grammar teaching constitutes an ill-defined domain. They also 
claim that research on grammar teaching have failed to yield a firm foundation for grammar teaching methodology that novice teachers can use as guidelines for their classroom practices. This situation leads to an ongoing process of constantly researching for a better understanding of grammar teaching and teachers' grammar teaching practices in the classrooms.

Language researchers (Burns and Knox, 2005; Edwards and Owen, 2005; Cots and Arno, 2005, Borg, 1998, 2005; Farrell and Lim, 2005; Ellis, 1998, 2006; Ting, 2007; Elsner, 2021) have argued that grammar education and prior coursework on English grammar that teacher trainees have experienced; and teacher trainees' cognition can exert certain impact on trainees' grammatical knowledge, pedagogical knowledge, pedagogical decisions and pedagogical reasoning in relation to the patterns of their grammar talk in the classrooms. Thus, this article presents findings and discussion based on a study which examines the patterns of teacher trainees' grammar talk that emerged from the grammar instruction they adopted in their classrooms.

\section{LITERATURE REVIEW}

In the following sections, current related research which forms the basis for this study will be discussed.

\section{Grammar Teaching}

Literature of LTE has highlighted issues about grammar teaching emphasising on methods and techniques for grammar teaching in the classrooms. It discusses the approaches, techniques and skills that teacher trainees should adopt in the teaching of grammar. There seems to be an overemphasis on teaching skills and not much focus is given on developing teacher trainees' independence and capacity to take charge of what they are doing in their grammar teaching and understanding grammar education (Johnson, 1994; Ellis, 2002; Borg, 1999; Burgess and Etherington, 2002; Gaudart, 2003; Schurz and Coumel, 2020). Despite literature on LTE has focussed on prescribing pedagogical choices that teacher trainees can implement in their grammar teaching, researchers note that they have yet to come up with firm foundation for grammar teaching practices that teacher trainees can use as guidelines for their grammar instruction. This leads to new development in grammar education and grammar teaching in LTE.

The current development of grammar education in LTE has promoted the concept of enhancing and developing teacher trainees' knowledge, ability and skills in grammar teaching through researching their classroom practices. This new direction of grammar education requires changes in the role play by teacher trainees. Teacher trainees are required to adopt active role in providing information to develop grammar education in LTE. Trainees must also learn to be autonomous learners and researchers whom can contribute to their own grammar learning and teaching (Wach, Zhang and Nichols-Besel, 2021). Teacher trainees should be taught on how to draw on their own knowledge, skills, beliefs and experiences in making decisions about their grammar teaching in various teaching situations. They must be given opportunities to gain investigative skills they need to make decisions as effective language teachers in terms of grammar teaching. This is in line with arguments by Richards and Nunan (1990) on the role 
of LTE. They write "the intent of second language teacher education must be to provide opportunities for the novice to acquire the skills and competencies of effective teachers and to discover the working rules that effective teachers use" (Richards and Nunan, 1990, p.15). One way of developing teacher trainees as effective teachers is by providing them with grammar education that can increase their awareness and skills in discovering what and why particular pedagogical practices would work best in which contexts for which students during grammar instruction (Fauziah, 2010).

Although awareness and efforts to advance grammar education in LTE has been increasingly promoted through research as well as training, there are still other issues that need equal attention. For instance, in the case of the Covid-19 pandemic, LTE has been greatly affected like in other sectors globally. Not only has it been challenging to address the need to provide sufficient support for grammar education in LTE, but it has also been difficult to provide conducive opportunity for teacher trainees to become actively involved in online classes. In a study conducted by Yastibas (2021) on LTE, the Covid-19 pandemic has forced classrooms to change from the conventional face-to-face mode to faceto-screen (Moorhouse, 2020). Among efforts made to address the challenge in grammar education in LTE was reported in a study by Wach, Zhang and Nichols-Besel (2021). They attempted to extend online grammar instruction among pre-service teachers through multinational telecollaboration during the Covic-19 crisis and discovered various benefits of providing an online platform to practise grammar teaching among teacher trainees from the United States, Poland and China. Such effort is not a norm but may serve as a way to support grammar education in LTE.

Approaches and Methods to Grammar Teaching

Many language educators believe that "L2 pedagogy needs to include the teaching of grammar as a foundational framework for all L2 skills" (Hinkel and Fotos, 2002, p.4). However, the complexity of grammar pedagogy in second language (L2) teaching has shown changes over time what constitutes effective approaches and methods to grammar teaching. Literature on grammar teaching has shown developments from traditional and structural approach of grammar teaching with deductive method in presenting grammar to communicative language teaching (CLT) approach with inductive or implicit grammar instruction (Navaz and Khaathoon, 2020; Abdulkarimova and Zubaydova, 2021). There is a shift to direct grammar teaching that focuses on forms but within meaning-focused activities.

In the past grammar teaching entails, the explicit presentation of discrete grammatical features. The aim is for learners to master grammatical rules and structures. This leads to the deductive method of presenting grammar. Language educators (Batstone, 1994; Doughty and Williams, 1998; Nunan, 2005; Cots and Arno, 2005; Macaro and Masterman, 2006, Berendse, 2012; Schurz and Coumel, 2020; Abdulkarimova and Zubaydova, 2021) claim language teachers in the past use the traditional Presentation-Practice-Production (PPP) model during their grammar instruction. Emphasis is given on declarative knowledge and teacher acts as a transmitter that demonstrates competence in terms of technical (declarative) knowledge and skills of the target language. Such grammar teaching approach aims to promote teachers who are experts in the subject matter and can impart content in their classrooms without much difficulty (Batstone, 1994).

Grammar teaching which is based on the PPP model has the characteristics of a teacher-fronted and transmission style classroom. This teacher-directed approach of grammar teaching utilises teacherbased instructional methods such as deductive grammar instruction and uses didactic questions that explicitly draw learners' attention to notice particular linguistic features. Such grammar teaching 
approach and method presented grammar in isolation and is viewed as inflexible (Johnson, 1994; CelceMurcia, 2002; Larsen-Freeman, 2001, Hinkel, 2013; (Navaz and Khaathoon, 2020). by language educators because it does not help language teachers to enhance their students' ability to use the target grammar.

The inflexibility of the teacher-fronted and transmission style grammar teaching forces language educators to explore other approaches and methods to grammar teaching. This leads to the approach of CLT in grammar instruction which aims to promote the understanding of meaning and language use. CLT addresses linguistic features within a meaning-based or communicative approach and teaching grammar in context (Larsen-Freeman, 2001; Nunan, 2005; Batstone, 1994). Teacher trainees are encouraged to teach grammar forms and structures in relation to context, meaning and use. The concept is teaching grammar as process and learners are given practices in language use and allow them to proceduralise target grammatical points or structures in question. Such grammar teaching approach emphasises on the procedural knowledge (PCK) or knowledge how to use grammar. Language educators (Nunan, 2005; Johnson, 1994; Celce-Murcia, 2002; Batstone; 1994; Hinkel, 2013; Navaz and Khaathoon, 2020) claim that CLT helps teacher trainees to understand how grammar can be taught through meaningful communication that not only meaning is conveyed but it is conveyed precisely and appropriately through interaction (Njika, 2020). However due to its focus on meaning and communication, grammar is usually inductively and implicitly addressed in CLT and fluency is stressed over accuracy (Abdulkarimova and Zubaydova, 2021).

Novice teachers and teacher trainees may find it difficult to present grammar in a context that can promote the relationship between grammatical forms and communicative function. This is noted by Gaudart (2003), Hanafi (1997) and Taghreed and Eman (2021) about teacher trainees in Malaysia. These teacher educators claim teacher trainees demonstrate difficulties to integrate grammar with language use and communication. As a result, most of their grammar instructions tend to move towards the extreme end which either focus on deploying grammatical points or rules or show overriding emphasis on meaning, language use and communication. Therefore, some alternative teaching approaches for grammar teaching that can integrate grammar into language skills and show how particular grammar points are used in real-life situations are viewed as viable means to increase teacher trainees' knowledge about grammar, knowledge on how to use grammar and knowledge on how to teach about grammar (Wach, Zhang and Nichols-Besel, 2021). Taghreed and Eman (2021) suggested that to provide an effective and practical way of showing how particular grammar points can be taught, teachers trainees should be exposed to watch real life social interactions that may be pre-recorded as part of the training to prepare them to plan for grammar lessons. Apart from that, they also recommended that the teacher trainees be allowed to observe lessons taught by in-service teachers to witness the different approaches that are being used for different types of learners in the classroom. This would not only be practical and useful for grammar education in face-to-face situations but also for online training like during the Covid-19 where real live social interactions or actual lessons taught by in-service teachers can either be watched life through online or pre-recorded. 


\section{RESEARCH QUESTION}

The research questions addressed in the study are:

a) How do teacher trainees present grammar in the language classroom?

b) What are the patterns that emerged in teacher trainees' grammar talk?

\section{THE STUDY}

The following sections will explain in detail the methodological approaches and considerations undertaken in this study.

\section{Participants}

The participants of this study were six teacher trainees of a Teaching English as a Second Language (TESL) programme in a public university in Malaysia. They underwent a three-month teaching practicum in secondary schools in order to gain experience to teach in a natural and formal setting as part of their LTE programme. All of them have no experience in language teaching except for the teaching experience from the microteaching course in their LTE. Pseudonyms were used for each participant in order to ensure the confidentiality of their names and identity.

\section{Design}

The study examined six teacher trainees' grammar instruction during their 3-month teaching practicum. Data were collected on the instructional strategies adopted by the trainees in terms of the skills and techniques they used in their grammar instruction.

\section{Classroom Data}

The researcher conducted four classroom observations on each trainee with a total of 320 minutes of observations. A total of twenty-four observations and 32 hours of observations were audio taped and transcribed. The data from the observation transcripts (recording transcripts of teacher trainees' grammar talk) were coded according to recurrent themes that were identified by researcher after several times of reading the transcripts [refer to Coffey and Atkinson, 1996, Dornyei, 2007 for a detailed explanation of how data transcripts can be coded according to themes] so that a coding scheme was constructed for the transcript data. Figure 1.0 shows the coding scheme developed after analysing the teacher talk (recording transcripts). The data from teacher talk were categorised under two major recurrent themes which were Transmission and Interaction (refer Appendix 1). 


\section{TEACHER TRAINEE GRAMMAR TALK}

Data from the recording transcripts of the participants' teacher talk showed two common patterns (transmission and interaction) emerged from analysis of teacher talk during grammar instruction. Transmission instructional skills and techniques involve teacher-fronted and one-way teacher-student relationship during the process of delivering grammar points. The second is interaction which encompasses an interactive technique in delivering grammar and a two-way relationship (teacherstudent-teacher) is developed during the grammar presentation. Figure 1.0 shows the skills and techniques demonstrated by teacher trainees in their grammar instruction which the techniques of explaining and demonstrating are categorised as Transmission and the techniques of questioning and corrective feedback is categorised as Interaction. The different categories of instructional skills and techniques coded in this study are quite similar to the analysis done by Borg (2005, 2003a, 2003b); Ellis (2006, 1998); Cots and Arno (2005); and Burns and Knox (2005) which these researchers study grammar teaching in terms of the specific behaviours demonstrated by teachers in their grammar teaching.

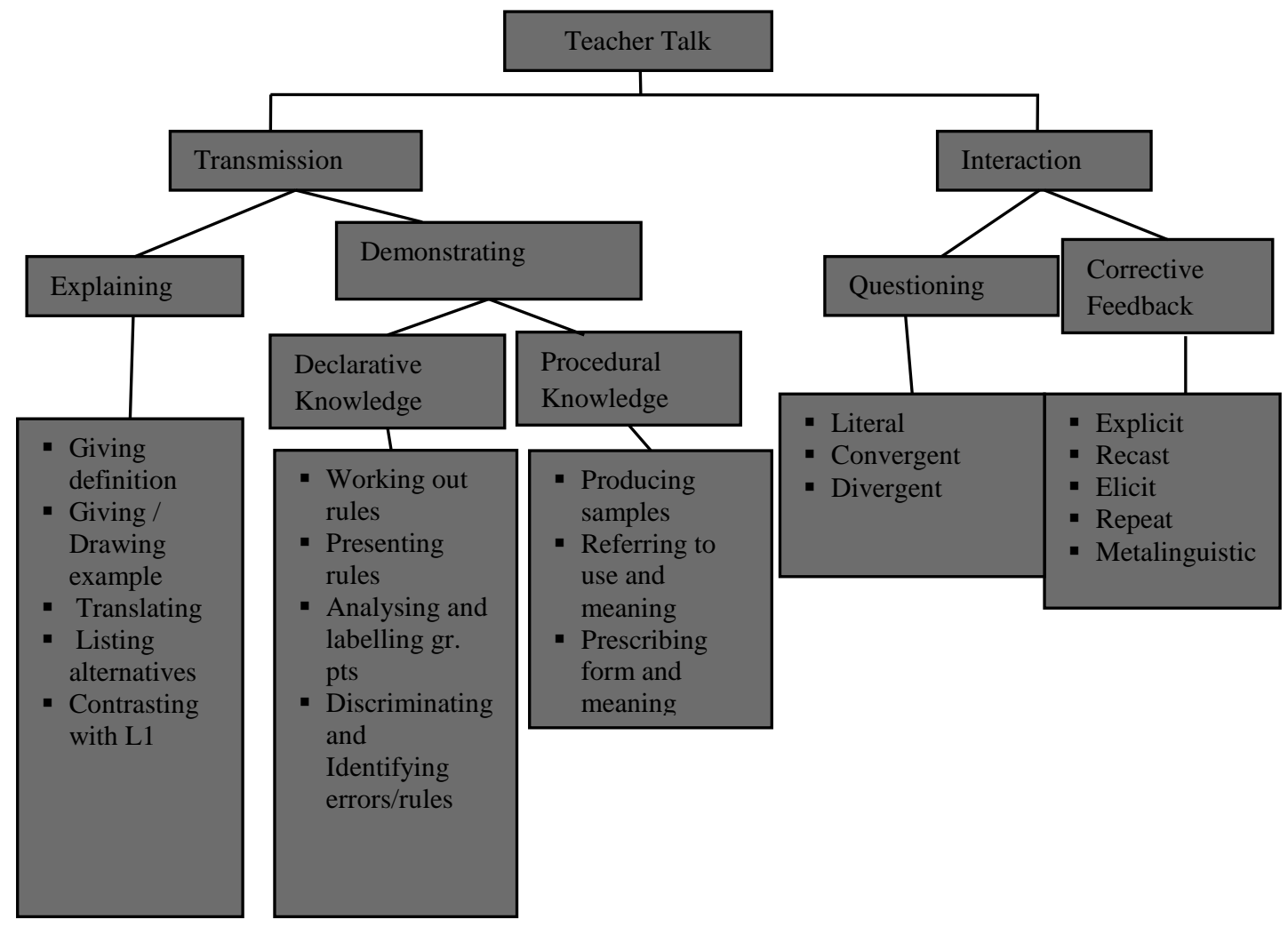

Figure 1.0 Transmission and interaction techniques demonstrated in teacher trainees' grammar talk 
One of the skills and techniques under transmission demonstrated by teacher trainees is explaining. This involves different techniques of explanation adopted by teacher trainees in presenting grammar. The techniques include explaining by giving definition; giving and drawing examples; translating to first language (L1); listing alternatives; and explaining grammar points by contrasting with L1. Explaining in the context of this study means different techniques of explanation demonstrated by teacher trainees in helping their students understand generalisations of grammar points or rules.

Another type of transmission skill and technique drawn from trainees' teacher talk is the technique of demonstrating grammar points in a lesson. The categorisation of demonstrating in this study is similar to Cots and Arno (2005) data categorisation of their study on language teachers' discipline knowledge in classroom practices. Demonstrating in this study means the techniques used by teacher trainees to enhance students understanding of a concept or grammar rules and structures. Two distinct techniques of demonstrating are identified. One is to present DK (or knowledge 'know about' the structure or rule; and the other is to demonstrate PCK or knowledge of 'being able to do' or the 'how to'). The first technique of demonstrating involves working out a grammar rule; presenting rules as formulas; analysing and labelling grammar points; and discriminating and identifying rules or errors (Cots and Arno, 2005; Johnson, 1994; Navaz and Khaathoon, 2020). The next technique of demonstrating focuses on language use such as producing samples; referring to use and meaning; and prescribing form and meaning (Cots and Arno, 2005, Johnson, 1994; Navaz and Khaathoon, 2020). The specific teaching behaviours demonstrated under transmission indicate a dominance of metalinguistic aspects in the lessons conducted by teacher trainees. These skills and techniques stress both on DK and PCK of grammar which focus on forms and the teaching of grammar as product (Johnson, 1994; Batstone, 1994; Doughty and Williams, 1998; Hinkel and Fotos, 2002; Ellis, 1998; Ellis, Basturkemen and Loewen, 2001; Burgess and Etherington, 2002; Nunan, 2005; Basturkemen et al., 2002; Berendse, 2012). Yet, there are also elements of teaching grammar as process or skills where meaning and language use for communication are stressed while teacher trainees are highlighting the 'how to' concept of the target grammar point or rule.

The second type of instructional skill and technique that is evident from trainees' teacher talk is interaction which encompasses questioning and giving corrective feedback. These two skills and techniques promote an interactive two-way teacher-student relationship while grammar is presented. The use of various question types such as literal questions, convergent questions and divergent questions were identified in the observation transcripts. Teacher trainees adopted both low-level and high-level thinking questions to draw students' responses on grammar points or structures. The questions teacher trainees used do not only result in interaction between teacher and students but also encourage students to give obvious answers, broad responses and opinions on grammar points or rules addressed in the lessons.

The types of questions posed by teacher trainees in this study are quite similar to the findings of Habsah's study (2006) on the techniques of questioning practiced by teachers in Malaysian classrooms. Besides questioning, teacher trainees also promote interaction during their grammar presentation by giving feedback or correcting students' errors. Five techniques of corrective feedback emerged from the transcripts which are quite similar to Ellis's explanation (1998) on giving feedback to students' incorrect utterances. They are explicit and immediate grammar feedback or correction; recast where teacher trainees reformulate students' utterances or errors in accordance with the correct language structure; 
teacher elicits correct form from students; teachers repeat students' utterances in order to draw their attention to the errors they made; and metalinguistic feedback where teacher trainees use technical term to refer to the errors made by their students.

The overall analysis of teacher trainees' grammar talk shows transmission and interaction techniques are frequently utilised in their instruction but transmission techniques are more dominant. There is a trend among the teacher trainees to adopt a teacher-fronted, transmission style classroom despite there are instances of using activities and tasks in the grammar presentation. Transmission techniques involve trainees doing the explaining and demonstrating of grammar points or rules. Table 1.0 and Table 2.0 display the frequency of transmission techniques in teacher trainees' grammar instruction.

Table 1 Frequency of transmission technique in trainees' teacher talk - technique of explaining

\begin{tabular}{|c|c|c|c|c|c|c|}
\hline \multicolumn{6}{|c|}{ Transmission - Technique of Explaining } & \multirow[t]{2}{*}{ Total } \\
\hline $\begin{array}{l}\text { Teacher } \\
\text { Trainee }\end{array}$ & Define & $\begin{array}{l}\text { Give/Draw } \\
\text { Example }\end{array}$ & Translate & $\begin{array}{l}\text { List } \\
\text { Alternatives }\end{array}$ & $\begin{array}{l}\text { Contrast } \\
\text { with L1 }\end{array}$ & \\
\hline & 23 & 35 & 1 & 2 & - & 61 \\
\hline \multicolumn{7}{|l|}{ Farida } \\
\hline & $37.70 \%$ & $57.38 \%$ & $1.64 \% \%$ & $3.28 \% \%$ & 0 & $100 \%$ \\
\hline \multirow[b]{2}{*}{ Nora } & 21 & 22 & 7 & 1 & 3 & 54 \\
\hline & $38.89 \%$ & $40.74 \%$ & $12.96 \%$ & $1.85 \%$ & $5.56 \%$ & $100 \%$ \\
\hline \multirow{2}{*}{ Ana } & 13 & 29 & - & 5 & - & 47 \\
\hline & $27.66 \%$ & $61.70 \%$ & 0 & $10.64 \%$ & 0 & $100 \%$ \\
\hline \multirow{2}{*}{ Wong } & 5 & 12 & - & - & - & 17 \\
\hline & $29.41 \%$ & $70.59 \%$ & 0 & 0 & 0 & $100 \%$ \\
\hline \multirow[b]{2}{*}{ Siti } & 24 & 48 & 4 & 4 & - & 80 \\
\hline & $30.00 \%$ & $60.00 \%$ & $5.00 \%$ & $5.00 \%$ & 0 & $100 \%$ \\
\hline \multirow{3}{*}{ Mei Ling } & 11 & 77 & 1 & 3 & - & 92 \\
\hline & & & & & & \\
\hline & $11.95 \%$ & $83.70 \%$ & $1.09 \%$ & $3.26 \%$ & 0 & $100 \%$ \\
\hline
\end{tabular}

Data in Table 1.0 illustrates teacher trainees' techniques of explanation. The explanation usually draws students to definitions and language examples. This is common in all teacher trainees' grammar instruction. The trainees frequently use examples either by giving examples or drawing examples from students when they are presenting general information on the target grammatical points. They consider this instructional strategy an "effective way" of introducing grammar because examples can directly draw students' attention to grammatical points and can therefore be time-saving (Berendse, 2012). As 
a result, giving and drawing examples dominated all teacher trainees' explaining techniques as illustrated by data in Table 1.0. This is an interesting finding because studies on teachers' grammar instruction have never noted that giving and drawing examples during grammar instruction can be viewed as an effective way of exposing students to general information about grammar (Fauziah, 2010).

Data in Table 1.0 also shows that teacher trainees provide definitions to language terms during their grammar explanation. Teacher trainees use grammar definitions in their teacher talk in order to draw students' attention to general information to grammar in a faster and precise way but they fail to note that knowing grammatical terms or definitions does not mean knowing grammar. This is argued by Celce-Murcia (2002) where she believes that metalinguistic terms and grammar definitions can serve as a referential function but they do not assure students can acquire knowledge on grammar mere knowing grammatical terminology.

Table 2.0 Frequency of transmission technique in trainees' teacher talk - technique of demonstrating

\begin{tabular}{|c|c|c|c|c|c|c|c|c|c|}
\hline \multirow{3}{*}{$\begin{array}{l}\text { Teacher } \\
\text { Trainee }\end{array}$} & \multicolumn{9}{|c|}{ Transmission - Technique of Demonstrating } \\
\hline & \multicolumn{5}{|c|}{ Declarative Knowledge } & \multicolumn{4}{|c|}{ Procedural Knowledge } \\
\hline & $\mathbf{W}$ & $\mathbf{P}$ & $\mathbf{A L}$ & DI & Total & PS & RE & $\mathbf{P F}$ & Total \\
\hline \multirow[t]{2}{*}{ Farida } & 59 & 52 & 33 & 10 & 154 & 3 & 5 & 18 & 26 \\
\hline & $38.31 \%$ & $33.77 \%$ & $21.43 \%$ & $6.49 \%$ & $100 \%$ & $11.54 \%$ & $19.23 \%$ & $69.23 \%$ & $100 \%$ \\
\hline \multirow[t]{2}{*}{ Nora } & 4 & 11 & 36 & 4 & 55 & 17 & 18 & 58 & 93 \\
\hline & $7.27 \%$ & $20.00 \%$ & $65.46 \%$ & $7.27 \%$ & $100 \%$ & $18.28 \%$ & $19.35 \%$ & $62.37 \%$ & $100 \%$ \\
\hline \multirow[t]{2}{*}{ Ana } & 11 & 8 & 17 & - & 36 & 15 & 17 & 1 & 33 \\
\hline & $30.56 \%$ & $22.22 \%$ & $47.22 \%$ & 0 & $100 \%$ & $45.45 \%$ & $51.52 \%$ & $3.03 \%$ & $100 \%$ \\
\hline \multirow[t]{2}{*}{ Wong } & 2 & 2 & 3 & - & 7 & 6 & 16 & 5 & 27 \\
\hline & $28.57 \%$ & $28.57 \%$ & $42.86 \%$ & 0 & $100 \%$ & $22.22 \%$ & $59.26 \%$ & $18.52 \%$ & $100 \%$ \\
\hline \multirow[t]{2}{*}{ Siti } & 13 & 13 & 46 & - & 72 & - & 18 & 11 & 29 \\
\hline & $18.06 \%$ & $18.06 \%$ & $63.88 \%$ & 0 & $100 \%$ & 0 & $62.07 \%$ & $37.93 \%$ & $100 \%$ \\
\hline \multirow[t]{2}{*}{ Mei Ling } & 4 & 11 & 13 & 16 & 44 & 18 & 16 & 11 & 45 \\
\hline & $9.09 \%$ & $25.00 \%$ & $29.55 \%$ & $36.36 \%$ & $100 \%$ & $40.00 \%$ & $35.56 \%$ & $24.44 \%$ & $100 \%$ \\
\hline
\end{tabular}


Table 2.0 also shows another type of transmission technique that is evident in trainees' teacher talk. Demonstrating techniques are significant in all teacher trainees' grammar talk. The common trend noted is that techniques of demonstrating are used to acquire or deepen students' understanding of grammar concepts or grammar structures. It is interesting to note that in integrated grammar presentation which is commonly linked with focus on language use and emphasis of procedural knowledge which means the teacher trainees' knowledge on how to use a particular grammar point (Cots and Arno, 2005), teacher trainees in this study still used demonstration techniques despite grammar points are highlighted implicitly or incidentally. Detail analysis of demonstration techniques indicate some demonstration techniques are more significantly used by teacher trainees compared to others. The pattern noted is that teacher trainees who stress on language analysis used demonstration techniques that promote both knowledge of grammar rules and knowledge on how to apply the grammar rules, but teacher trainees that stress on language use adopted techniques that promote procedural knowledge.

The overall analysis of teacher trainees' grammar instruction also shows another instructional technique that had emerged throughout their teacher talk but not as dominant as transmission. Interaction techniques that promote two- way technique of presenting grammar (teacher-studentteacher relationship) are discussed in terms of the questioning techniques and giving corrective feedback deploy by teacher trainees during the teaching process. Questioning is more significantly used compared to giving corrective feedback. This is shown by the data in Table 3.0.

Table 3 Frequency of interaction technique in trainees' teacher talk

\begin{tabular}{|c|c|c|c|c|c|c|c|c|c|c|}
\hline \multicolumn{11}{|c|}{ Interaction } \\
\hline \multicolumn{5}{|c|}{ Technique of Questioning } & \multicolumn{6}{|c|}{ Technique of Corrective Feedback } \\
\hline $\begin{array}{l}\text { Teacher } \\
\text { Trainee }\end{array}$ & $\begin{array}{c}\text { Lite } \\
\text { ral }\end{array}$ & $\begin{array}{c}\text { Conver } \\
\text { gent }\end{array}$ & $\begin{array}{c}\text { Diverg } \\
\text { ent }\end{array}$ & $\begin{array}{c}\text { Tot } \\
\text { al }\end{array}$ & $\begin{array}{l}\text { Exp } \\
\text { licit }\end{array}$ & $\begin{array}{c}\text { Rec } \\
\text { ast }\end{array}$ & $\begin{array}{c}\text { Elic } \\
\text { it }\end{array}$ & $\begin{array}{c}\text { Rep } \\
\text { eat }\end{array}$ & $\begin{array}{c}\text { Meta } \\
- \\
\text { lingui } \\
\text { stic }\end{array}$ & $\begin{array}{c}\text { Tot } \\
\text { al/ } \\
\%\end{array}$ \\
\hline \multirow[t]{3}{*}{ Farida } & 41 & 33 & 1 & 75 & 10 & - & 4 & 1 & 2 & 17 \\
\hline & 54.6 & 44.00 & 1.33 & 100 & 58.8 & 0 & 23.5 & 5.88 & 11.77 & 100 \\
\hline & 7 & & & $\%$ & 2 & & 3 & & & $\%$ \\
\hline \multirow[t]{3}{*}{ Nora } & 49 & 6 & 4 & 59 & 11 & 1 & 2 & 4 & 2 & 20 \\
\hline & 83.0 & 10.17 & 6.78 & 100 & 55.0 & 5.00 & 10.0 & 20.0 & 10.00 & 100 \\
\hline & 5 & & & $\%$ & 0 & & 0 & 0 & & $\%$ \\
\hline Ana & 29 & 11 & 5 & 45 & 3 & 1 & 2 & - & 2 & 8 \\
\hline
\end{tabular}




\begin{tabular}{|c|c|c|c|c|c|c|c|c|c|c|}
\hline \multicolumn{11}{|c|}{ Interaction } \\
\hline \multirow{5}{*}{ Wong } & 64.4 & 24.45 & 11.11 & 100 & 37.5 & 12.5 & 25.0 & 0 & 25.00 & 100 \\
\hline & 4 & & & $\%$ & 0 & 0 & 0 & & & $\%$ \\
\hline & 7 & 3 & - & 10 & 4 & - & 2 & - & 1 & 7 \\
\hline & 70.0 & 30.00 & 0 & 100 & 57.1 & 0 & 28.5 & 0 & 14.29 & 100 \\
\hline & 0 & & & $\%$ & 4 & & 7 & & & $\%$ \\
\hline \multirow[t]{3}{*}{ Siti } & 25 & 18 & - & 43 & - & - & - & 1 & 2 & 3 \\
\hline & 58.1 & 41.86 & 0 & 100 & 0 & 0 & 0 & 33.3 & 66.67 & 100 \\
\hline & 4 & & & $\%$ & & & & 3 & & $\%$ \\
\hline Mei & 18 & 5 & - & 23 & 14 & - & 4 & - & 4 & 22 \\
\hline \multicolumn{11}{|l|}{ Ling } \\
\hline & 78.2 & 21.74 & 0 & 100 & 63.6 & 0 & 18.1 & 0 & 18.18 & 100 \\
\hline & 6 & & & $\%$ & 4 & & 8 & & & $\%$ \\
\hline
\end{tabular}

All trainees seem to favour using literal or low-level thinking questions in their grammar instruction. Even though questions are supposedly to promote interaction in a classroom, dominant use of literal questions does not allow much room for interactive discussion between teacher and students. This is because literal questions do not challenge students' thinking process because they do not promote broad responses from students (Sahin et al., 2002; Njika, 2020). This questioning pattern supports Habsah's findings (2006) on the dimensions of questioning in Malaysian classrooms. She claims that there seems to be a preference to use literal and convergent questions in teachers' instruction (Habsah, 2006). Researchers (Sahin, Bullock and Stables, 2002) argue that low-level thinking questions discourage higher-order thinking processes among students and they can lead to teacher-fronted style classroom because such instructional strategy still refers to teacher as the input provider and the "allknowing" feeder of knowledge. This is seen as a common trend in this study where grammar presentation is very much teacher-fronted even though there are instances of interaction techniques noted.

The analysis of teacher talk in the study indicates there are some efforts by teacher trainees to permit interaction through their techniques of giving corrective feedback. But the common trend still signals a teacher-fronted style corrective feedback. Data in Table 3.0 show teacher trainees' preference for explicit and immediate corrective feedback. This is also confirmed by the responses they gave in their interview and teaching journals as presented in the case studies. They claim that explicit feedback made students "notice and remember their errors directly", thus this can avoid them from repeating and fossilising the errors they made. Some researchers (Ellis, 1998; Larsen-Freeman, 2001) point out that explicit grammar feedback is the fastest and precise manner to make students aware of the errors 
they made but such technique of corrective feedback does not allow much interaction (Njika, 2020). This is in line with the overall pattern of teacher trainees' teacher talk which shows transmission techniques (one-way interaction) outnumbered interaction techniques (two-way interaction). Other techniques of corrective feedback which can promote interaction and encourage students' thinking process such as elicitation and recast are minimally utilised by teacher trainees in this study. Ellis (1998) notes that elicitation and clarification request can help learners to give the correct form through interactive teacher-student exchange. But in this study there is very minimal utilisation of elicitation and none of the trainees employ clarification request. These findings lead to another important point to note in terms of what aspects of grammar teaching options can be exposed to teacher trainees in order to encourage them to utilise more interactive grammar instruction.

\section{CONCLUSION}

This article has reported how teacher trainees presented grammar in the language classroom and shows the patterns that emerged from the trainees' grammar talk. It is noted that teacher trainee's grammar instruction is very much teacher-fronted and transmission in nature. The patterns of teacher trainee grammar talk noted in this article enable teacher trainees and teacher educators to understand the instructional strategies adopted by novice when presenting grammar points and at the same time can create awareness of the effects of teacher trainees' choices in adopting particular instructional strategies as their grammar instructions. Thus, this article can provide both teacher trainees and teacher educators with useful information to make more informed decisions on grammar instruction by adopting not only transmission techniques but also interaction techniques which allow grammar to be presented in a more meaningful manner.

\section{REFERENCES}

Abdulkarimova, N. A. and Zubaydova, N. N. 2021. Deductive and Inductive Approaches to Teaching Grammar. Proceedings of International scientific-Practical Conference on Cognitive Research in Education. 372-376.

Azar, B. 2007. Grammar-based Teaching: A Practitioner's Perspective. TESL-EJ. 11(2): 1-12.

Basturkmen, H., Loewen, S.; and Ellis, R. 2002. Metalanguage in Focus on Form in the Communicative Classroom. Language Awareness. 11(1): 1-13.

Batstone, R. 1994. Product and Process: Grammar in the Second Language Classroom. In M. Bygate, A. Tonkyn, and E. Williams (Eds.). Grammar and the Language Teacher. New York: Prentice Hall. 224-236.

Berendse, E. 2012. A Comparison between the Effectiveness of Inductive and Deductive Instruction in the L2 English Classroom in a L1 Dutch Environment. Published Bachelor Thesis, Utrecht University, Netherlands. 
Borg, S. 1998. Teachers' Pedagogical Systems and Grammar Teaching: A Qualitative Study. ,TESOL Quarterly. 32(1): 9-37.

Borg, S. 1999b. Teachers' Theories in Grammar Teaching. ELT Journal. 53(3): 157-167.

Borg, S. 2003a. Teacher Cognition in Grammar Teaching: A Literature Review. Language Awareness. 12(3): 96-108.

Borg, S. 2003b. Knowing and Doing: Teaching Grammar in In-service Training. In D. Liu, and P. Master (Eds.). Grammar Teaching in Teacher Education . USA: TESOL Inc. 75-88.

Borg, S. 2005. A Case Study of the Development in Pedagogic Thinking of a Pre-service Teacher. TESLEJ. 9(2): 1-26.

Borg, S. 2006. Teacher Cognition and Language Education. London: Continuum.

Burgess, J., and Etherington, S. 2002. Focus on Grammatical Form: Explicit or Implicit? System. 30(4): 433-458.

Burns, A., and Knox, J. 2005. Realisation(s): Systemic Functional Linguistics and the Language Classroom. In N. Bartels (Ed.). Applied Linguistics and Language Teacher Education . U.S.A: Springer. 235-260.

Celce-Murcia, M. 2002. Why it Makes Sense to Teach Grammar in Context and Through Discourse. In E. Hinkel, and S. Fotos (Eds.). New Perspectives on Grammar Teaching in Second Language Classrooms. New Jersey: Lawrence Erlbaum Associates Publishers. 119-134.

Coffey, A., and Atkinson, P. 1996. Making Sense of Qualitative Data. Thousand Oaks: Sage Publications. Cots, J. M., and Arno, E. 2005. Integrating Language Teachers' Discipline Knowledge in a Language Course. In N. Bartels (Ed.). Applied Linguistics and Language Teacher Education. U.S.A: Springer. 59-78.

Dornyei, Z. 2007. Research Methods in Applied Linguistics. Oxford: Oxford University Press.

Doughty, C.; and Williams, J. (Eds.). 1998. Focus on Form in Classroom Second Language Acquisition. USA: Cambridge University Press.

Edwards, C.; and Owen, C. 2005. The Impact on Teachers of Language Variation as a Course Component. In N. Bartels (Ed.). Applied Linguistics and Language Teacher Education. U.S.A: Springer. 43-58.

Ellis, R. 1998. Teaching and Research: Options in Grammar Teaching. TESOL Quarterly. 32(1): 39-57. Ellis, R. 2002. The Place of Grammar Instruction in the Second/Foreign Language Curriculum. In E. Hinkel, and S. Fotos (Eds.). New Perspectives on Grammar Teaching in Second Language Classrooms. New Jersey: Lawrence Erlbaum Associates Publishers. 17-34.

Ellis, R. 2006. Current Issues in the Teaching of Grammar: An SLA Perspective. TESOL Quarterly. 40(1): 83-107.

Elsner, D. 2021. Knowledge About Grammar and the Role of Epistemological Beliefs. Pedagogical Linguistics. 2(2). Doi: 10.1075/pl.21003.els

Farrell, T. S. C., and Lim, P. C. P. 2005. Conceptions of Grammar Teaching: A Case Study of Teachers' Beliefs and Classroom Practices. TESL-EJ. 9(2): 1-13.

Fauziah Ismail. 2010. Factors and Challenges Influencing Grammar Teaching in the Teaching Practicum. Unpublished Doctoral Thesis. Universiti Teknologi Malaysia, Malaysia.

Gaudart, H. 2003. English Language Teaching Practices. Malaysia: Sasbadi Sdn. Bhd. 
Habsah Hussin. 2006. Dimensions of Questioning: A Qualitative Study of Current Classroom Practice in Malaysia. TESL-EJ. 10(2): 1-18.

Hanafi Mohamed Kamal. 1997. The Malaysian English Language Classroom in the Next Millennium: Challenges and Concerns. In G. M. Jacobs (Ed.). Language Classrooms of Tomorrow: Issues and Responses. Singapore: SEAMEO RELC. 78-90.

Hinkel, E. and Fotos, S. (Eds.). 2002. New Perspectives on Grammar Teaching in Second Language Classrooms. New Jersey: Lawrence Erlbaum Associates.

Hinkel, E. 2013. Research Findings on Teaching Grammar for Academic Writing. English Tecahing. 68(4): 3-21.

Johnson, K. E. 1994. Teaching Declarative and Procedural Knowledge. In M. Bygate, A. Tonkyn, and A. Williams (Eds.). Grammar and the Language Teacher . New York: Prentice Hall. 121-131.

Larsen-Freeman, D. 2001. Teaching Grammar. In M. Celce-Murcia (Ed.). Language Teaching Approaches: An Overview . United States: Heinle and Heinle. 251-266.

Macaro, E., and Masterman, L. 2006. Does Intensive Explicit Grammar Instruction Make All the Difference? Language Teaching Research. 10(3): 297-327.

Moorhouse, B. L. 2020. Adaptations to a Face-to-face Initial Teacher Education Course 'Forced' Online Due to the COVID-19 Pandemic. Journal of Education for Teaching. 46(4): 609-611. Retrieved from https://www.tandfonline.com/doi/full/10.1080/02607476.2020.1755205.

Navaz, A. M. N., and Khaathoon, M. F. 2020. Teaching Grammar: A Comparison Between Schools and University. KALAM-International Research Journal. 13(4): 58-70.

Njika, J. A. 2020. Exploring Pre-service Tecahers' Perception of Interactional Activities in Lasson Planning. English Language Teaching. 13(3): 92-99.

Nunan, D. 2005. Practical English Language Teaching: Grammar. Singapore: McGraw Hill.

Richards, J. C., and Nunan, D. (Eds.). 1990. Second Language Teacher Education. USA: Cambridge University Press.

Sahin, C., Bullock, K., and Stables, A. 2002. Teachers' Beliefs and Practices in Relation to Their Beliefs About Questioning at Key Stage 2. Educational Studies. 28(4): 371-384.

Schurz, A., and Coumel, M. 2020. Grammar Teaching in ELT: A Cross-national Comparison of Teacherreported Practices. Language Teaching Research. 1-26.

Taghreed El Masry and Eman I Alzaanin. 2021. Uncovering New Paths to Adaptation: A Case Study of Malaysian English as a Second lnaguage Pre-service Teachers. Arab World English Journal. 112(1.28): 421-442.

Ting, S. H. 2007. Is Teacher Education Making an Impact on TESL Teacher Trainees' Beliefs and Practices of Grammar Teaching? English Language Teacher Education and Development. 10: 4262.

Wach, A., Zhang, D., and Nichols-Besel, K. 2021. Grammar Instruction Through Multinational Telecollaboration for Pre-Service Tecahers. ReCALL. 1-17. Doi:10.1017/S0958344021000112.

Yastibas, A. E. 2021. Preparing Pre-Service English Language Teachers to Teach at Unprecedented Times: The Case of Turkey. Journal of English Teaching. 7(1): 1-14. 